\title{
施設園芸の地域的集中と拡散
}

坂本英 夫

ガラス温室, ビニールハウス, ビニールトンネル等の保温防寒設備を利用して, 花や 果樹，野菜類を栽培すること，すなわら施設園芸は，近年，各地で非常に普及してい る。その状況については，いくつかの報告があるが，地域的な動向についての関心はあ まり寄せられていない。ガラス温室の分布に関しては, 松井貞雄氏の報告がある。本稿 では，対象の枠をガラス温室に限定せず，生産手段の集約化として施設園芸をとらえ， その地域的展開を考察することに焦点を拈いた。その方法として, 主に, 施設園芸にお ける生産手段を，昭和38年と昭和 48 年との実績によって比較しょうとした。昭和 38 年を 比較の基準にとったのは，この期がいわゆるハウスやトンネルの普及第一期の終了点で あり，次への展開のはじまりであったからである。また，「十年一昔」といわれるよう に，10年というものは，歴史的時間の最小単位と考兄られるからである。な拉，利用の 幅を広くするために，統計はあまり加工しないようにしたが，原資料にある坪などの単 位は, ha やa換算した。

経済地理学会第22回大会では，農業に乱ける主産地形成という問題が，テーマから必 然的に生まれて，討論に時間が割かれた。筆者も報告者のひとりして，技術の普及と資 本の投下，蓄積の問題にふれようとしたが，十分な論議を尽すには至らなかった。それ は，一つには，共通資料の不足といらことが考兄られる。本稿を提出することが，必ず しも上記の問題の解答にはならないとしても, 日本的な農業の資本集約化の一過程を理 解するための補助資料になると考兄られる。

1）たとえば，横木清太郎：施設園芸の進展と施設利用の経済性，農業と経済（1970）36-3， pp. $11 \sim 17$.

丸山恵三 : わが国施設園芸の実態と今後の方向, 農業と経済 (1973）39-12, pp. 52〜60.

2）松井貞雄 : 温室園芸地域の特産地化, 地理学評論 (1971) 44-4, pp. 241 253.

松井貞雄 : 温室園芸地域の変貌, 地理 (1974) 19-3, pp. 11 23.

3）農林省園芸局 : 園芸用ガラス室, フレーム等の設置状況について（昭和 37 年 7 月〜 38年 6 月実 績) (1964）農業ビニール協会。

農林省食品流通局野菜振興課 : 園芸用ガラス室, 八ウス等の設置状況（昭和 47 年 7 月〜昭和 48 年 6 月間実翌) (1974), 日本施設園芸協会。

4) 経済地理学会第22回大会, 昭和50年 5 月 18 日, 於一橋大学, シンポジウム「農業地理学の課題 一商品生産の地域的展開」 


\section{1 施設園芸の面積}

ガラス温室をはじめ, 強化プラスチック, ビニール, ポリエチレン, 寒冷紗等で被覆 された骨組施設即ちハウスと，トンネルの三種を，広義に施設園芸と呼んでいる。字義 通りに解釈すれば，フレームや霜除けも含めてよいことになるし，現場の農政関係者は ハウスだけを施設園芸の意味するものとしてとらえている。しかし，ここでは，本稿の 目的に従う為，上記三種を施設園芸の施設とした。

施設園芸の中で，最も資本集約的な 施設は，いうまでもなくガラス温室で あるが，八ウスやトンネルに比べると， 施設面積は小さい（第 1 表）。面積は, 10年間にいずれも増加しているが，比 率は, 昭和38年に, ガラス温室 : ハウ ス：トンネル =1:9:57であったのが, 昭和48年には, $1: 19: 47$ と変化して, ハウスの面積拡大が著しい。トンネル 栽培は, 昭和38年以前にすでに普及し ており，その伸びはにぶい。

第 1 表 施設園芸の設置面積 (ha)

\begin{tabular}{|c|c|c|c|}
\hline & & 昭和38年 & 昭和 48 年 \\
\hline ガラス温室 & $\begin{array}{l}\text { 面 積 } \\
\text { らち加温 }\end{array}$ & $\begin{array}{l}395 \\
145\end{array}$ & $\begin{array}{r}1,035 \\
750\end{array}$ \\
\hline 八ウ ス & $\begin{array}{l}\text { 面 積 } \\
\text { らち加温 }\end{array}$ & $\begin{array}{r}3,707 \\
441\end{array}$ & $\begin{array}{r}20,096 \\
8,522\end{array}$ \\
\hline トンネル & 面 積※ & 22,517 & 47,392 \\
\hline
\end{tabular}

はなく通路を含んだほ場全面積をいう。

資料 : 農林省園芸局 : 園芸用ガラス室, フレーム等の設 置状況について（昭和37年 7 月 38年 6 月間実績） 農業ビニール協会, 昭和39年

農林省食品流通局野菜振興課：園芸用ガラス室， ハウス等の設置状況（昭和 47 年 7 月 48年 6 月間実 績）日本施設園芸協会, 昭和 49 年

ガラス温室の分布 ガラス温室の地域的集中はきわめて著しいことで知られてい る。たとえば, 愛知・静岡・岡山の三県で, 全国のガラス温室の面積の $62 \%$ 占めてい るし，上位14都府県で $90 \%$ 占めている (第 2 表)。この10年間に，ぞこもガラス温室 は増加したが，とくに目立つのは愛知県で, その他広島, 三重, 埼玉, 大阪, 岐阜, 滋 賀で増㝋ている。また，面積そのものはまだ小さいが，東北地方や北陸での伸びが大き い。これに対して、トップグループにありながら, 静岡県と岡山県の伸びがあまり大き くないし，東京や千葉も同様である。これは，過剰生産(メロン・ブドウ・トマトなど) と他の適作物転換が遅れていることから来ている。ガラス温室を経営する農家は, 全国 の農家の $0.4 \%$ に過ぎない。静岡, 愛知, 岡山の三県が $2 \%$ 台であり, 神奈川, 東京で さえ $1 \%$ 台という程度である。ガラス温室は特殊な局限された分布を示しており，その 県なり, 地方（例えば, 瀬戸内）を代表する農業型にまで拡がる可能性は, 当分の間, 考壳られない。

資本集約化の方向として，加温装置の有無がある。昭和38年に，加温装置をつけてい ないガラス温室は 250 ha あったが，全国的にその後は殆んど増えていない。つまり， 
第 2 表 園芸用ガラス温室の設置面積

\begin{tabular}{|c|c|c|c|c|c|c|c|c|}
\hline & 昭 和 & 38 年 & \multicolumn{2}{|r|}{ 昭 } & \multicolumn{3}{|c|}{ 年 } \\
\hline & & $\begin{array}{c}\text { 設備面積 } \\
\text { ha }\end{array}$ & $\begin{array}{c}\text { 加温設備 } \\
\text { ha }\end{array}$ & $\begin{array}{c}\text { 設備面積 } \\
\text { ha } \\
\end{array}$ & $\begin{array}{c}\text { 加温設備 } \\
\text { ha }\end{array}$ & $\begin{array}{c}\text { 自動灌水 } \\
\text { ha }\end{array}$ & $\begin{array}{l}\text { 启当面積 } \\
\mathrm{a}(ア ー ル)\end{array}$ & $\begin{array}{l}\text { 室農家率 } \\
\%\end{array}$ \\
\hline 合 & 計 & 395 & 145 & 1,035 & 750 & 309 & 5.1 & 0.40 \\
\hline 北 海 & 道 & 1 & 1 & 3 & 3 & 1 & 3.3 & 0.07 \\
\hline 青 & 森 & 0 & 0 & 0 & 0 & 0 & 2.4 & 0.01 \\
\hline 岩 & 手 & 0 & 0 & 1 & 1 & 0 & 2.4 & 0.02 \\
\hline 宮 & 城 & 3 & 3 & 9 & 9 & 7 & 4.7 & 0.16 \\
\hline 秋 & 田 & 0 & 0 & 0 & 0 & 0 & 2.0 & 0.02 \\
\hline 山 & 形 & 0 & 0 & 1 & 1 & 1 & 1.8 & 0.05 \\
\hline 福 & 島 & 1 & 1 & 5 & 5 & 1 & 3.2 & 0.10 \\
\hline 茨 & 城 & 4 & 1 & 8 & 8 & 3 & 5.4 & 0.08 \\
\hline 栃 & 木 & 0 & 0 & 4 & 4 & 3 & 5.6 & 0.06 \\
\hline 群 & 馬 & 0 & 0 & 2 & 2 & 2 & 1.8 & 0.09 \\
\hline 埼 & 玉 & 6 & 6 & 20 & 20 & 1 & 2.3 & 0.64 \\
\hline 千 & 葉 & 27 & 3 & 48 & 47 & 9 & 6.6 & 0.46 \\
\hline 東 & 京 & 5 & 3 & 12 & 12 & 5 & 3.3 & 1.09 \\
\hline 神 奈 & 川 & 21 & 20 & 57 & 55 & 42 & 5.9 & 1.76 \\
\hline 新 & 潟 & 1 & 1 & 4 & 4 & 0 & 2.0 & 0.11 \\
\hline 富 & 山 & 0 & 0 & 3 & 2 & 1. & 3.2 & 0.13 \\
\hline 石 & 川 & 1 & 0 & 2 & 2 & 1 & 1.6 & 0.20 \\
\hline 福 & 井 & 0 & 0 & 2 & 2 & 1 & 1.9 & 0.18 \\
\hline 山 & 梨 & 6 & 1. & 5 & 4 & 5 & 2.1 & 0.37 \\
\hline 長 & 野 & 1 & 1 & 4 & 4 & 0 & 3.0 & 0.07 \\
\hline 岐 & 阜 & 2 & 1 & 15 & 14 & 3 & 6.1 & 0.02 \\
\hline 静 & 岡 & 86 & 45 & 193 & 169 & 46 & 4.7 & 2.79 \\
\hline 愛 & 知 & 73 & 19 & 258 & 162 & 104 & 6.0 & 2. 59 \\
\hline 三 & 重 & 3 & 1 & 24 & 23 & 6 & 6.3 & 0.33 \\
\hline 滋 & 賀 & 3 & 2 & 14 & 14 & 12 & 12.9 & 0.12 \\
\hline 京 & 都 & 1 & 0 & 5 & 4 & 2 & 4.0 & 0.17 \\
\hline 大 & 阪 & 5 & 2 & 17 & 13 & 7 & 3.7 & 0.78 \\
\hline 兵 & 庫 & 16 & 6 & 42 & 39 & 16 & 5.6 & 0.43 \\
\hline 奈 & 良 & 0 & 0 & 5 & 4 & 1 & 4.3 & 0.21 \\
\hline 和 歌 & 山 & 2 & 0 & 5 & 4 & 3 & 5.8 & 0.14 \\
\hline 鳥 & 取 & 0 & 0 & 1 & 1 & 0 & 3.2 & 0.06 \\
\hline 島 & 根 & 0 & 0 & 1 & 1 & 0 & 1.1 & 0.16 \\
\hline 岡 & 山 & 94 & 12 & 192 & 58 & 4 & 6.0 & 2. 19 \\
\hline 広 & 島 & 7 & 4 & 27 & 20 & 3 & 8.2 & 0.23 \\
\hline 山 & 口 & 2 & 0 & 6 & 5 & 1 & 3.2 & 0.17 \\
\hline 徳 & 島 & 1 & 0 & 7 & 7 & 5 & 3.4 & 0.28 \\
\hline 香 & 川 & 7 & 2 & 16 & 13 & 3 & 5.4 & 0.38 \\
\hline 愛 & 媛 & 1 & 0 & 2 & 1 & 1 & 2.4 & 0.06 \\
\hline 高 & 知 & 1 & 1 & 0 & 0 & 0 & 5.5 & 0.01 \\
\hline 福 & 岡 & 4 & 2 & 7 & 7 & 4 & 3.1 & 0.15 \\
\hline 佐 & 賀 & 0 & 0 & 1 & 1 & 0 & 5.3 & 0.01 \\
\hline 長 & 崎 & 1 & 1 & 2 & 1 & 1 & 3.2 & 0.05 \\
\hline 熊 & 本 & 4 & 2 & 1 & 1 & 0 & 3.7 & 0.03 \\
\hline 大 & 分 & 1 & 1 & 3 & 2 & 1 & 3.8 & 0.06 \\
\hline 宮 & 崎 & 1 & 0 & 1 & 0 & 0 & 3.0 & 0.02 \\
\hline 鹿 児 & 島 & 1 & 0 & 1 & 1 & 1 & 5.5 & 0.01 \\
\hline
\end{tabular}

資料 : 第 1 表に同じ 
無加温ガラス室の比重は全国的に低下しているとみなすことができる。この中にあって， 愛知, 岡山の二県で, 無加温ガラス室の絶対面積が横這いあるいは増加をみていること は, 両県がガラス温室利用の先行産地（主産地）だけに，話題を提起することになる う。大都市及びその近郊でのガラス温室は加温装備率が高く, しかもその傾向を強化し てきている(東京, 神奈川, 埼玉, 大阪)。また, 北海道, 東北, 北陸などの寒冷地で の加温装置の装備率の高いことも注目される。特に, 積雪の多い地方では, 加温の有無 は重要な結果をもたらす。

自動灌水装置の装備率が比較的高いのは, 愛知県之東京, 神奈川, 大阪などの大都市 地域ならびに東北や九州などにみられる。一戸当りの面積は, 滋賀県が最大であるが, 概して古い産地の場合が大きく，新興地は小さい。しかし，東京，埼玉，大阪などの大 都市および近郊では狭小化傾向にある。

ガラス温室の建造そのものは資本の集約化になるわけであるが，以上を通観してみる と, 愛知・静岡・岡山の三県は面積的な集中が著しいが，質的な装備の充実性という点 では，それぞれの内部にかなりの粗密差があることが看取される。大都市ならびにとの 近郊はガラス温室立地が最も早い時期にみられたところであるが，面積は相対的に狭小 化している。しかし, 各種装備は高度化してきている。これらに対して, 新しい産地 は，その中にいろいろなタイプがあるが，装備は概してすぐれて和り，開設の当初から 最新式の設備を目指して建設することが考兄られる。

ハウスならびにトンネルハウスならびにトンネルの地域的分布は, 集中化の著し いガラス温室の場合とは傾向を異にする。簡単にい党ば，八ウスは地域的拡散傾向を示 し，トンネルは地域的拡散もあるが地域的集中もみられる，といらことである。 八ウスにおいては，昭和38年当時，かなり地域的集中性を示していた。すなわち，高 知県だけで28\%を占め，その他上位の県を加えた 4 県で55\%の面積を占めていた。しか し, 各地にハウス園芸が普及して, 特定地域への集中性は弱まり, 上位 4 県で $30 \%$ と下 っている。しかし, この中にあって, 先行産地である高知県のみは, 設備を高度化して 括り, 昭和 48 年に, 加温設備をもつもの $86.7 \%$, 自動灌水施設を有するもの $56.2 \%$, 他の主要産地の追従を許さない。高知県は, すでに, 昭和38年に八ウスに加温設備をい ち早くとり入れ，その面積は全国の57\%と，他を圧していた。

しかし，八ウス園芸で見逃せないのは新興の茨城・栃木・熊本・宮崎の諸県である。 設備の充実も進んでいるし，とりわ壮，1戸当りの経営面積が大きいことが，今後の可 能性を含んでいる。 
第 3 表 ハウス設置面積

(ha)

\begin{tabular}{|c|c|c|c|c|c|c|c|c|}
\hline & \multicolumn{2}{|c|}{ 昭 和 38 年 } & \multicolumn{2}{|r|}{ 昭 } & 和 & \multicolumn{2}{|l|}{ 年 } \\
\hline & & 総 数 & らち加温 & 総 数 & らち加温 & 自動灌水 & 二户当り & $\begin{array}{l}\text { 晋家率 } \\
\end{array}$ \\
\hline 総 & 数 & 3,132 & 339 & 20,096 & 8,522 & 7,837 & $10.5 \mathrm{a}$ & $3.73 \%$ \\
\hline 北 海 & 道 & 10 & 10 & 220 & 97 & 84 & 3.9 & 3.80 \\
\hline 青 & 森 & 1 & 0 & 68 & 19 & 13 & 4. 0 & 1.52 \\
\hline 岩 & 手 & 1 & 0 & 63 & 22 & 35 & 4.9 & 1.04 \\
\hline 宮 & 城 & 6 & 1 & 253 & 161 & 214 & 10.1 & 2. 10 \\
\hline 秋 & 田 & 4 & 1 & 29 & 17 & 8 & 4.9 & 0.51 \\
\hline 山 & 形 & 2 & 0 & 108 & 38 & 43 & 2.9 & 3.45 \\
\hline 福 & 島 & 4 & 1 & 299 & 123 & 126 & 8.6 & 2.20 \\
\hline 茨 & 城 & 17 & 6 & 1,192 & 332 & 455 & 16.9 & 3.78 \\
\hline 栃 & 木 & 20 & 2 & 1,181 & 488 & 446 & 14.1 & 7. 49 \\
\hline 群 & 馬 & 30 & 2 & 656 & 285 & 410 & 10.5 & 5.42 \\
\hline 埼 & 玉 & 80 & 38 & 756 & 471 & 252 & 8.7 & 6.18 \\
\hline 千 & 葉 & 270 & 0 & 754 & 416 & 29 & 9.1 & 5.30 \\
\hline 東 & 京 & 15 & 0 & 47 & 22 & 11 & 4.1 & 3. 39 \\
\hline 神奈 & 川 & 51. & 16 & 190 & 153 & 136 & 8.8 & 3.98 \\
\hline 新 & 潟 & 17 & 13 & 212 & 60 & 28 & 5.1 & 2.20 \\
\hline 富 & 山 & 7 & 1 & 32 & 8 & 6 & 4.6 & 0.93 \\
\hline 石 & 川 & 6 & 1 & 109 & 14 & 15 & 10.3 & 1.56 \\
\hline 福 & 井 & 21 & 3 & 55 & 13 & 24 & 9.1 & 1.03 \\
\hline 山 & 梨 & 47 & 0 & 479 & 381 & 155 & 13.6 & 4.99 \\
\hline 長 & 野 & 16 & 0 & 314 & 89 & 3 & 4.6 & 3.33 \\
\hline 岐 & 阜 & 53 & 0 & 453 & 115 & 94 & 10.1 & 3.60 \\
\hline 静 & 岡 & 336 & 7 & 907 & 356 & 266 & 9.0 & 6.92 \\
\hline 愛 & 知 & 252 & 13 & 1,092 & 483 & 260 & 11.1 & 5.98 \\
\hline$\equiv$ & 重 & 29 & 0 & 222 & 43 & 66 & 11.2 & 1.75 \\
\hline 滋 & 賀 & 4 & 1 & 49 & 21 & 24 & 6.9 & 0.83 \\
\hline 京 & 都 & 13 & 0 & 83 & 13 & 8 & 8.0 & 1. 51 \\
\hline 大 & 阪 & 16 & 1 & 474 & 43 & 59 & 13.8 & 5.77 \\
\hline 兵 & 庫 & 76 & 0 & 327 & 113 & 98 & 9.6 & 1.96 \\
\hline 奈 & 良 & 44 & 0 & 646 & 172 & 364 & 13.5 & 8.79 \\
\hline 和 歌 & 山 & 42 & 2 & 180 & 26 & 165 & 8.6 & 3.27 \\
\hline 鳥 & 取 & 14 & 1 & 207 & 16 & 87 & 8.0 & 4. 69 \\
\hline 島 & 根 & 1 & 0 & 297 & 45 & 130 & 12.4 & 2.86 \\
\hline 岡 & 山 & 151 & 2 & 413 & 150 & 54 & 8.8 & 3.20 \\
\hline 広 & 島 & 64 & 3 & 277 & 128 & 111 & 6.0 & 3.20 \\
\hline 山 & 口 & 2 & 0 & 136 & 38 & 56 & 4.4 & 3.08 \\
\hline 徳 & 島 & 135 & 0 & 384 & 118 & 260 & 9.8 & 5.71 \\
\hline 香 & 川 & 18 & 0 & 419 & 86 & 214 & 8.8 & 6.28 \\
\hline 愛 & 媛 & 18 & 0 & 145 & 65 & 60 & 8.2 & 1.60 \\
\hline 高 & 知 & 881 & 194 & 1,591 & 1,380 & 895 & 13.0 & 11.24 \\
\hline 福 & 岡 & 59 & 5 & 762 & 440 & 648 & 10.6 & 4.98 \\
\hline 佐 & 賀 & 15 & 0 & 202 & 48 & 113 & 11.1 & 2.65 \\
\hline 長 & 崎 & 13 & 0 & 176 & 42 & 53 & 7.4 & 2.70 \\
\hline 熊 & 本 & 74 & 9 & 2,066 & 429 & 322 & 17.5 & 8.18 \\
\hline 大 & 分 & 30 & 1 & 193 & 109 & 111 & 3.0 & 1. 93 \\
\hline 宮 & 崎 & 133 & 0 & 946 & 589 & 593 & 14.9 & 6.71 \\
\hline 鹿 児 & 島 & 30 & 1 & 395 & 221 & 229 & 10.0 & 1.89 \\
\hline 沖 & 縄 & & & 35 & 4 & 5 & 3.6 & \\
\hline
\end{tabular}

凟料 : 第 1 表に同じ, ハウス農家率の農家数は, 農林省統計情報部：第49次農林省統計表．農林統計協 会, 昭 49 年による 
全農家に占めるハウス経営農家の割合は，全国で

第 4 表 トンネル栽培面積 (ha)

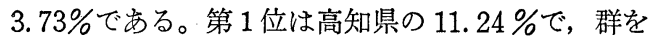
拔いて高い。そのあとを $8 \%$ 台の奈良，熊本，7\% 台の杤木が続く。これら上位の 4 県は, 前記のガラ ス温室普及度の低い県であり，しかも最近 20 年間に 野菜生産が急激に伸びたところである。

トンネル栽培は，ハウスよりも早い時期に全国的 に普及していたこともあって，昭和38年—昭和 48 年の面積の伸びは 2.2 倍にしかなっていないが，地 域的分布は興味ある傾向を示している。まず，(1)近 年, 地域的集中の動きがみられる。上位 6 県では, 昭和 38 年 $38 \%$ —昭和 48 年 $50 \%$ と占有率が高まった。 とくに，東関東や南九州の増加は注目される。(2)寒 冷地の東北地方や長野県あるいは山陰地方での伸び

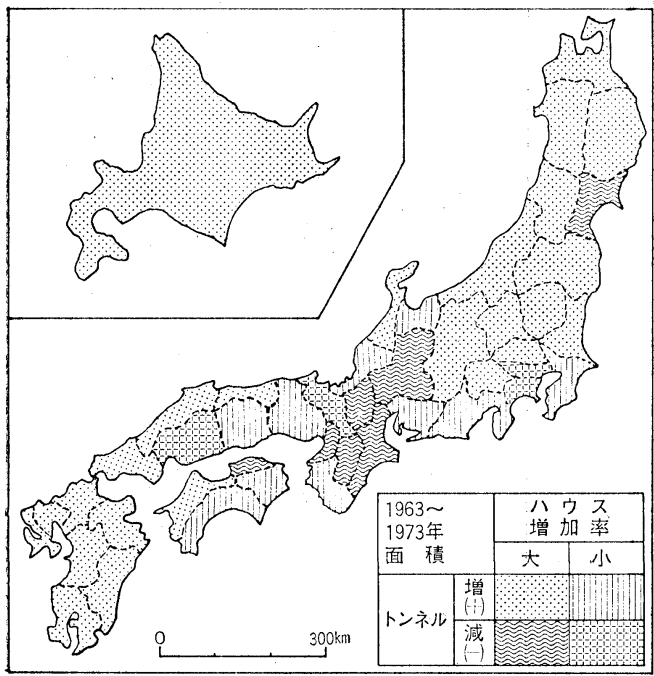

第1図 ビニールハウスおよびトンネル栽培の普 及状況

〔基準〕1，八ウス，全国平均増加率の6.42より大，小 2.トンネル, 絶対数 (面積) の増減

\begin{tabular}{|c|c|c|c|}
\hline & & 昭和38年 & 昭和 48 年 \\
\hline 総 & 数 & 22,517 & 47,392 \\
\hline 北 海 & 道 & 990 & 2,162 \\
\hline 青 & 森 & 24 & 1,210 \\
\hline 岩 & 手 & 237 & 310 \\
\hline 宮 & 城 & 380 & 344 \\
\hline 秋 & 田 & 30 & 773 \\
\hline 山 & 形 & 157 & 741 \\
\hline 福 & 島 & 181 & 297 \\
\hline 茨 & 城 & 545 & 5,021 \\
\hline 栃 & 木 & 415 & 633 \\
\hline 群 & 馬 & 517 & 1,805 \\
\hline 埼 & 玉 & 1,980 & 4,049 \\
\hline 千 & 葉 & 1,562 & 7,040 \\
\hline 東 & 京 & 529 & 229 \\
\hline 神奈 & 川 & 1,339 & 853 \\
\hline 新 & 潟 & 264 & 440 \\
\hline 富 & 山 & 192 & 248 \\
\hline 石 & 川 & 174 & 316 \\
\hline 福 & 井 & 102 & 136 \\
\hline 山 & 梨 & 138 & 204 \\
\hline 長 & 野 & 73 & 351 \\
\hline 岐 & 阜 & 496 & 365 \\
\hline 静 & 岡 & 386 & 1,341 \\
\hline 愛 & '知 & 935 & 3,847 \\
\hline$\equiv$ & 重 & 738 & 255 \\
\hline 滋 & 賀 & 258 & 180 \\
\hline 京 & 都 & 534 & 421 \\
\hline 大 & 阪 & 1,273 & 507 \\
\hline 兵 & 庫 & 422 & 701 \\
\hline 奈 & 良 & 1,353 & 337 \\
\hline 和 歌 & 山 & 161 & 780 \\
\hline 鳥 & 取 & 33 & 527 \\
\hline 島 & 根 & 83 & 107 \\
\hline 岡 & 山 & 176 & 554 \\
\hline 広 & 島 & 310 & 270 \\
\hline 山 & 口 & 126 & 248 \\
\hline 徳 & 島 & 444 & 614 \\
\hline 香 & 川 & 1,215 & 988 \\
\hline 愛 & 媛 & 163 & 450 \\
\hline 高 & 知 & 555 & 818 \\
\hline 福 & 岡 & 750 & 1,137 \\
\hline 佐 & 賀 & 99 & 228 \\
\hline 長 & 崎 & 276 & 493 \\
\hline 熊 & 本 & 627 & 2,649 \\
\hline 大 & 分 & 279 & 384 \\
\hline 宮 & 崎 & 746 & 1,059 \\
\hline 鹿 児 & 島 & 250 & 882 \\
\hline 沖 & 縄 & & 89 \\
\hline
\end{tabular}

資料：第 1 表に同じ 
が著しい。これは，普及の段階が二次的にずれた，という解釈が考えられる。(3)都市 圏では面積が減少しているところが目立つ。

また，いくつかの県でも減少が文られるが，この場合は，それぞれハウスの伸び率が 全国平均の伸び率（6.4 倍）を上廻っていることから，トンネル栽培よりもハウス経営 に重点をおきかえた者が多いためであろうと考方られる。

\section{2 施設園芸における野菜生産概況}

概況 ガラス温室では, 野菜>花弁>果樹の順に栽培が多い。野菜といっても，その

第 5 表 施設園芸の栽培作物

\begin{tabular}{|c|c|c|c|c|c|c|c|}
\hline & \multicolumn{2}{|c|}{ ガ ラ ス 室 } & \multicolumn{2}{|l|}{ 八 } & \multicolumn{2}{|c|}{ トンネル } \\
\hline & & 昭和38年 & 昭和 48 年 & 昭和38年 & 昭和 48 年 & 昭和 38 年 & 昭和48年 \\
\hline 野 & 菜 & 376 . & 913 & 3,381 & 21,585 & 22,334 & 48,199 \\
\hline 花 & き & 223 & 611 & 266 & 1,571 & 187 & 323 \\
\hline 果 & 樹 ha & 96 & 185 & 59 & 1,298 & - & 1 \\
\hline 合 & 計 ha & 695 & 1,709 & 3,706 & 24,454 & 22,521 & 48,523 \\
\hline & 用率\% & 176 & 165 & 118 & 122 & 100 & 102 \\
\hline
\end{tabular}

資料は第 1 表汇同じ

第 6 表 施設園芸における野菜栽培面積 (ha)

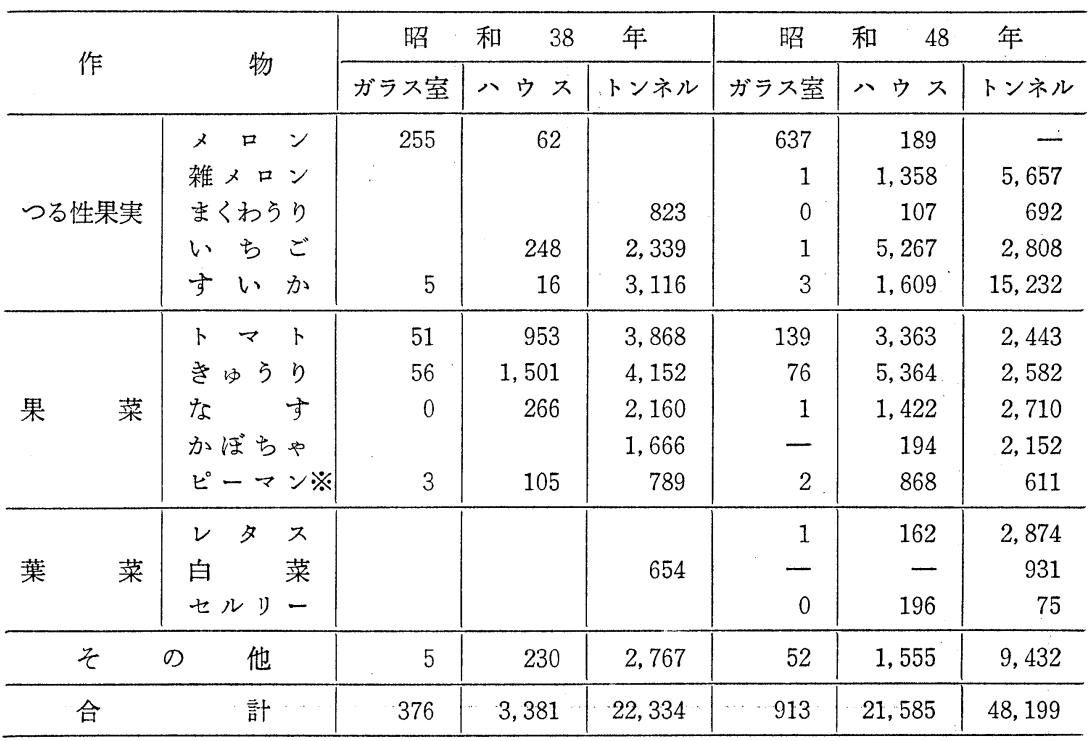

※、昭和38年はあおとうがらしを含む

資料 : 第 1 表汇同し 
大部分はメロンであり，果樹の場合はブドウである。作物の栽培延面積が温室面積を上 廻っているのは, 二毛作あるいは三毛作を行なっているからである。稼動率を高めて, 固定費負担を軽減せしめようとする努力がうかがえる。ハウスならびにトンネルでは, 野菜類の栽培を目的としているものが多く， 八ウスでは $88 \%$ ，トンネルでは $99 \%$ ド野菜 栽培面積である。

施設園芸で栽培される主な野菜類は第 6 表の如くであり，10年間にかなりの推移がみ られる。ガラス温室では，メロンが唯一といってもよい程の適作物で，他に高収益のあ ゲられる野菜類のないのが悩みである。イチゴ,トマト，キュウリなどは，以前，トン ネル栽培が多かったが，八ウス栽培へ移行してきた。ハウスでは，長期にわたる栽培の

第 7 表 昭和 48 年ガラス温室の栽培作物

(単位 10ha)

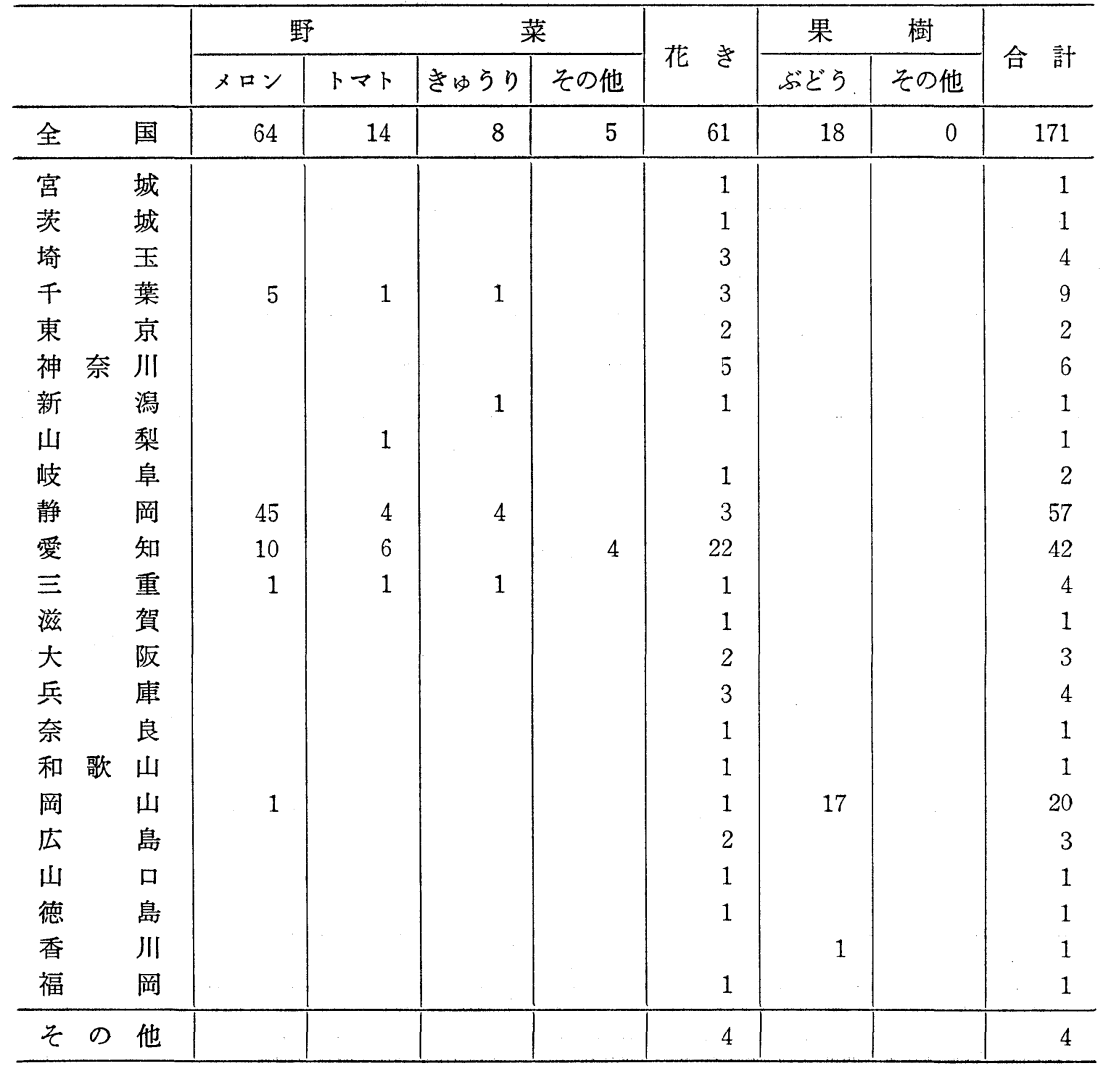

資料：第 1 表に同じ 
第 8 表 昭和38年ガラス温室の主要栽培作物

(単位 10ha)

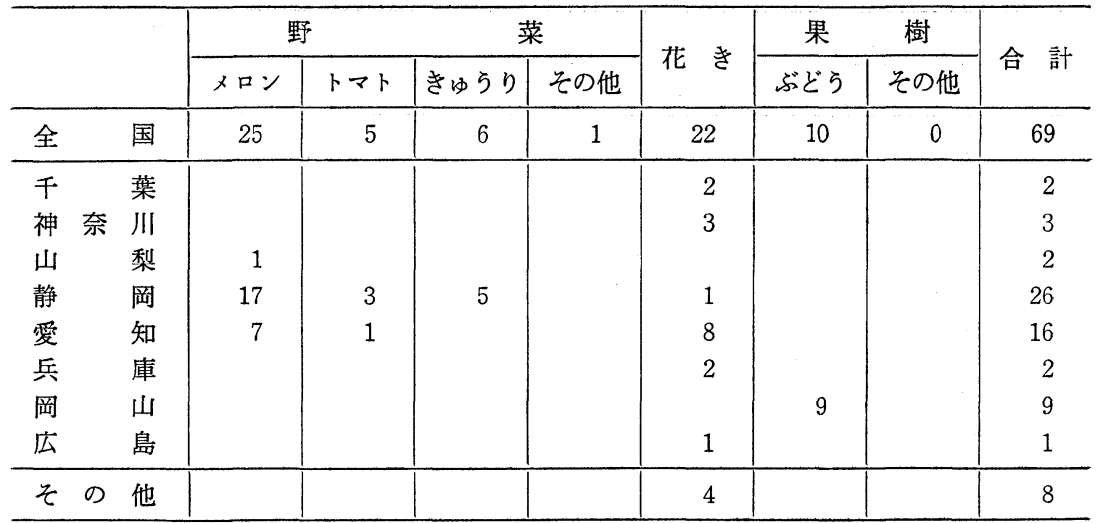

資料 : 第 1 表に同じ

結果, 数量が期待できる野菜類が増えているのに対して, トンネルでは単価のやや低い スイカや雑メロン(プリンスなど)，マクワウリなどの半促成栽培が普及している。野 菜類も単価が低いため, トンネルで防霜・保温が行われる程度である。

ガラス温室の栽培作物 地域的集中性という点では, ガラス温室で栽培される作物 はその典型的なものであろう（第 7，8表)。メロンは静岡県, 花卉は愛知県, ブドウ は岡山県と, 代表的な産地を一言でいえるほど明瞭な地域的集中を示している。この傾 向は，10年間にほとんど変っていない。メロンやブドウなど，高度の技術を要し，しか

第 9 表 昭和38年ハウス栽培の野菜

(単位 100ha)

\begin{tabular}{|c|c|c|c|c|c|c|c|c|c|}
\hline & & きゅらり & トマト & な す & いちご & すいか & $\begin{array}{l}\text { そうが } \\
ら し \%\end{array}$ & その他 & 合 計 \\
\hline 全 & 国 & 15 & 10 & 3 & 2 & 0 & 1 & 3 & 34 \\
\hline 埼 & 玉 & 1 & & & & & & & 1 \\
\hline 千 & 葉 & 1 & 2 & & & & & & 3 \\
\hline 岐 & 阜 & & 1 & & & & & & 1 \\
\hline 静 & 岡 & 1 & 1 & & 2 & & & & 4 \\
\hline 愛 & 知 & 1 & 1 & 1 & & & & & 3 \\
\hline 岡 & 山 & 1 & & & & & & & 1 \\
\hline 徳 & 島 & 1 & & 1 & & & & & 2 \\
\hline 高 & 知 & 6 & 1 & 1 & & & & 1 & 9 \\
\hline 宮 & 崎 & 1 & & & & & & & 1 \\
\hline そ の & 他 & 2 & 4 & 0 & 0 & 0 & 1 & 2 & 9 \\
\hline
\end{tabular}

※ ピーマンを含む $100 \mathrm{ha}$ 末満は四搭五入, 各県欄の 0 は記入を省略

資料：第 1 表们同じ 
第10表＼cjkstart昭和48年ハウス栽培の野菜

(単位 100ha)

\begin{tabular}{|c|c|c|c|c|c|c|c|c|c|}
\hline & 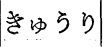 & トマト & なす & いちご & すいか & |ピーマン & 雑メロン & その他 & 合 計 \\
\hline 全 国 & 54 & 34 & 14 & 53 & 16 & 9 & 14 & 23 & 216 \\
\hline 北海道 & & 1 & & 1 & & & & & 2 \\
\hline 宮 城 & 1 & & & 1 & & & & & 3 \\
\hline 山 形 & 1 & & & & & & & & 2 \\
\hline 福 島 & 1 & & & 1 & & & & 1 & 3 \\
\hline 茨 城 & 4 & 3 & & 1 & 4 & 2 & & & 16 \\
\hline 栃 木 & 2 & 2 & & 9 & & & & & 13 \\
\hline 群 馬 & 5 & 2 & & 2 & & & & & 10 \\
\hline 埼 玉 & 5 & 1 & 1 & 2 & & & & & 10 \\
\hline 千葉 & 4 & 4 & & 1 & & & & & 10 \\
\hline 神奈川 & 1 & 1 & & & & & & & 3 \\
\hline 新 潟 & 1 & 1 & & & & & & & 2 \\
\hline 福 井 & & 1 & & & & & & & 1. \\
\hline 山 梨 & 1 & & & 1 & & & & & 3 \\
\hline 岐 阜 & & 1 & & 3 & & & & & 5 \\
\hline 静 岡 & 1 & 2 & & 5 & & & & 1 & 10 \\
\hline 愛 知 & 2 & 2 & 2 & 2 & 1 & & 1 & 1 & 12 \\
\hline 三 重 & . & 1 & & 1 & & & & & 3 \\
\hline 大 阪 & & & & 1 & & & & 2 & 5 \\
\hline 兵 庫 & & 1 & & 1 & & & & & 3 \\
\hline 奈 良 & & & & 5 & & & & & 6 \\
\hline 和歌山 & & & & 1 & & & & & 2 \\
\hline 鳥 取 & & & & 1 & & & & & 2 \\
\hline 岡 山 & & & & 1 & & & & & 2 \\
\hline 広 島 & 1 & & & 1 & & & & & 3 \\
\hline 山 口 & & & & 1 & & & & & 2 \\
\hline 德 島 & 1. & & & 1 & & & & & 3 \\
\hline 香 川 & & & & 2 & & & & & 2 \\
\hline 高 知 & 7 & 1 & 4 & & 1 & 3 & & 2 & 19 \\
\hline 福 岡 & 1 & 1 & 1 & 2 & & & & & 6 \\
\hline 佐 賀 & & & & 1 & & & & & 2 \\
\hline 熊 本 & 1 & 3 & 1 & 1 & 7 & & 9 & 1 & 22 \\
\hline 大 分 & & & & 1 & & & & & 2 \\
\hline 宮 崎 & 4 & 1 & & & 1 & 1 & & 1 & 11 \\
\hline 鹿児島 & 1 & 1 & & 1 & & & & & 5 \\
\hline その他 & 2 & & & & & & & 9 & 11 \\
\hline
\end{tabular}

$100 \mathrm{ha}$ 未満は四捨五入, 各県欄の 0 は記入を省略

資料：第 1 表汇同じ

も，市場での銘柄成確立されたものは, 特定産地の独占性が非常に高いことになる。花 卉類は地域的集中性が比較的低いが，これは，そこに含まれる作物の種類が多種多様で 
あることに基づく。原資料は「花卉」で一括されているが，たと壳ば，電照菊だけをと り出したら，愛知県が大部分を占めてしまうことにならう。

昭和38年には, 第 8 表に出ていなかった都府県で, 昭和48年に第 7 表に名を出したも のは15あるが，その内には，花卉類の栽培だけで名乗りをあげている都府県がある。第 7 表と第 8 表を見比べるとき，産地の拡散がおこったように感じられるのはこのためで ある。生活水準の上昇に伴って，花卉類の生産が全国各地で盛んになっていることを示 す。花卉類といっても無数にあり，新興産地は比較的資本のかからない，技術の容易な ものから着手するであろうし, 古くからの産地は, より高級品を狙ってゆく。第 7 表で は，埼玉，東京，神奈川，大阪などの大都市ならびにその近郊に立地する花卉園芸の勃

第11表 昭和38年トンネル栽培の野菜 (単位 100ha)

\begin{tabular}{|c|c|c|c|c|c|c|c|c|c|c|}
\hline & きゅうり & トマト & なす & いちご & すいか & $\begin{array}{l}\text { とらか } \\
\text { らし }\end{array}$ & 壮ちゃ & 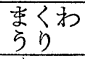 & その他 & 合 計 \\
\hline 全 国 & 41 & 38 & 21 & 23 & 31 & 8 & 17 & 8 & 34 & 223 \\
\hline 北海道 & 3 & 3 & 1 & & & & & & 2 & 10 \\
\hline 宮 城 & 1 & & & & & & & & 1 & 4 \\
\hline 茨 城 & 1 & 1 & & & 1 & & & & & 5 \\
\hline 栃 木 & & & & 2 & & & & & & 4 \\
\hline 群 馬 & 1 & & 1 & & & & & & 1 & 5 \\
\hline 埼 玉 & 5 & 1 & 3 & 4 & & & & & 6 & 20 \\
\hline 千 葉 & 3 & 4 & & 1 & 1 & 2 & & & 4 & 16 \\
\hline 東 京 & 1 & 1 & 1 & & & & & & 1 & 5 \\
\hline 神奈川 & 4 & 3 & 1 & & 2 & & & & 2 & 13 \\
\hline 新 潟 & & 1 & & & & & & & & 3 \\
\hline 静 岡 & & & & 2 & & & & & & 4 \\
\hline 岐 阜 & & & & 1 & & & & & 1 & 5 \\
\hline 愛 知 & 2 & 2 & 1 & 2 & & & & & 1 & 9 \\
\hline 三 重 & 1 & 2 & & & & & & & 2 & 7 \\
\hline 京 都 & 1 & & 2 & & & & & & & 5 \\
\hline 大阪 & 4 & 3 & 3 & & & & & & 2 & 13 \\
\hline 兵 庫 & & 1 & & & & & & & 1 & 4 \\
\hline 奈 良 & 1 & 2 & & 3 & 3 & & & 1 & 2 & 14 \\
\hline 徳 島 & & & & & 3 & & & & & 4 \\
\hline 香 川 & & & & & 7 & & 3 & & & 12 \\
\hline 高 知 & & & & & 4 & & 1 & & 1 & 6 \\
\hline 福 岡 & & 1 & & 1 & & & & & & 7 \\
\hline 熊 本 & 2 & & & & & & 2 & & 1 & 6 \\
\hline 宮 崎 & 1 & & 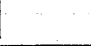 & & & 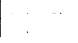 & 5 & & & 7 \\
\hline その他 & 8 & 8 & 3 & 2 & 4 & 1 & 1 & 1 & 6 & 35 \\
\hline
\end{tabular}

100ha 未满は四唅五入. 各県欄の 0 は記入を省略 ※ピーマンを含む 資料：第 1 表泟同し 
興が注目をひくが，宮城，福岡などの地方の広域中心都市でもガラス温室による花卉生 産が盛んになってきたことも見逃せない傾向である。

ハウスおよびトンネルによる野菜作の分布、ハウス栽培される野菜の種類も増加し，

第12表 昭和48年トソネル栽培の野菜

(単位 100ha)

\begin{tabular}{|c|c|c|c|c|c|c|c|c|c|c|}
\hline & きゅうり & トマト & なす & いちご & すいか & かぼちゃ & $\begin{array}{l}\text { 雑メ口 } \\
\text { 氺 }\end{array}$ & レタス & その他 & 合 計 \\
\hline 全 国 & 26 & 24 & 27 & 28 & 152 & 22 & 64 & 29 & 110 & 482 \\
\hline 北海道 & 1 & 1 & & 1 & 8 & 2 & 4 & 1 & 2 & 23 \\
\hline 青 森 & 1 & 1 & & & 10 & & 2 & & & 14 \\
\hline 岩 手 & 1 & 1 & 1 & & & & & & & 4 \\
\hline 秋 田 & & & & & 5 & & 1 & & & 8 \\
\hline 山 形 & 2 & 1 & & 1 & & & 3 & & & 7 \\
\hline 茨 城 & 1 & 3 & 4 & 1 & 19 & 4 & 10 & 2 & 7 & 50 \\
\hline 栃 木 & & 1 & 1 & 2 & & & 1 & & 1 & 6 \\
\hline 群 馬 & 1 & 1 & 3 & & 8 & & 1 & & 4 & 18 \\
\hline 埼 玉 & 3 & 2 & 6 & 5 & 1 & & 2 & 4 & 17 & 40 \\
\hline 千葉 & 2 & 3 & 1 & & 20 & 1 & 4 & 4 & 35 & 70 \\
\hline 神奈川 & 2 & & 1 & 1 & 1 & & & 1 & & 9 \\
\hline 新 潟 & & 1 & & & 3 & & & & & 4 \\
\hline 石 川 & & & & & 1 & & 1 & & & 3 \\
\hline 長 野 & & 1 & & & & & & & & 4 \\
\hline 静 岡 & & & & & 6 & & & 5 & & 13 \\
\hline 愛 知 & & & 1 & 1 & 22 & 2 & 9 & 1 & & 38 \\
\hline 京 都 & 1 & & 2 & & & & & & 1 & 4 \\
\hline 大 阪 & 1 & 1 & 1 & 1 & & & & & 2 & 5 \\
\hline 兵 庫 & & 1 & & 1 & 2 & & & 1 & 1 & 7 \\
\hline 奈 良 & & & & 1 & 1 & & & & & 3 \\
\hline 和歌山 & & & 1 & & 5 & & & 1 & 2 & 9 \\
\hline 鳥 取 & & & & & 3 & & 1 & & & 5 \\
\hline 岡山 & & & & 1 & 1 & 1 & & & & 5 \\
\hline 德 島 & & & & & 2 & & & & 3 & 6 \\
\hline 香 川 & & & & & 1 & 2 & 1 & 4 & 1 & 10 \\
\hline 高 知 & & & & & 2 & & & & 6 & 9 \\
\hline 福 岡 & & & & 4 & 1 & 1 & 2 & 1 & 2 & 11 \\
\hline 長 崎 & & & & & 1 & & 2 & & & 5 \\
\hline 熊 本 & & & & & 14 & 2 & 7 & 1 & 2 & 26 \\
\hline 大 分 & & & & & 3 & & 1 & & 1 & 6 \\
\hline 宮 崎 & & & & & 3 & 3 & 3 & & & 11 \\
\hline 鹿児島 & & & & & 3 & 1 & 3 & & 1 & 9 \\
\hline その他 & 5 & 5 & 4 & 4 & 7 & 2 & 3 & 2 & 9 & 41 \\
\hline
\end{tabular}

100ha 未満は四唅五入. 各県欄の 0 は記入を省略

※ まくわうりを含む

資料：第 1 表汪同じ 
また，各地に拡散したことは，第 9 表と第10表を比較してみるとよくわかる。古い産地 として, 高知県は相変らず大きな産地の地位を占めて拉り, 高度な技術を要するナス, ピーマンに比重を括いている。首都圏をやや離れたところにある関東諸県（茨城・枋木 ·群馬・埼玉 ·千葉) のハウス野菜の増加は著しいものがある。九州では熊本・宮崎の 伸びが大きく，とくに熊本県はスイカ，プリンスメロンの大産地に成長した。

トンネル栽培も, 各地に分散傾向がみられる。しかし, ガラス温室やハウスの作物分 布と異なる地域にそれがみられる。つまり，古くから園芸が盛んで有名であったという ようなところよりも, むしろ, 新興の産地にトンネル利用の栽培が盛んになっている傾 向がみられる。青森県の屏風山砂丘地でのスイカ作はその好例である。スイカ, 雑メロ ン類は, 単価の割に広い土地を要求するので, 連作回避の上からも, 経営耕地の大きさ が必要である。東関東の台地, 愛知県東部の畑地带, 熊本平野, とか各地の開拓地で伸 びている。ハウス栽培と同様に, 関東地方のトンネル栽培が増加している。東京, 神奈 川あるいは大阪のような大都市地域では後退傾向にあり, 露地栽培ほどではないが, ト ンネル栽培は大都市近郊の景観ではなくなりつつある。ハウス園芸の盛んな高知県はト ンネル方式はふるわない。温暖性を売物にするには，トンネル栽培は効率があがらない からである。

\section{3 技術の普及と産地の新旧}

ガラス温室の普及が，他の施設園芸ほど著しくないのは，固定資本額が非常に大きい からである。たとえば,トマト（10 a 当り, 昭和 $44 \cdot 45 \cdot 46$ 年平均) ではトンネル（半 促成）で 197,045 円，八ウスの半促成で 451, 065 円，促成では 472, 722 円であるのに対 して, 温室では 1,203,022 円と桁はずれに高い。したがって, よほど単価の高い作物を 大量に生産して，粗収益をあげなければ，損益分岐点の位置が高くなって採算がとれな くなる惧れが生ずる。

ビニールハウスは, 固定資本部分がガラス温室の $40 \%$ 程度ですむし, また, 総生産費 に対する労働報酬額がほとんど変らない（温室 2.07 , 八ウス 1.99)。したがって, 温室 に比べて，八ウスは資本の小さいわが国の農家には受け入れやすい設備投資であるとい えよう。

第二次大戦後, 青果物の生産が地域的に集中化と分散が同時併行的に進行することに

5）農林省統計調查部：昭和44年産野菜・果実生産費 (1971), 農林統計協会 農林省統計調查部：昭和45年産野菜生産費 (1972), 農林統計協会 農林省統計情報部：昭和46年産野菜生産費 (1973), 農林統計協会

6）坂本英夫：近年に拈ける野菜産地の地域的展開（1976）, 地理21-2, pp. 80〜94. 
ついては, 早くから指摘されていだ。とくに, 山田定市は, 野菜の産地が全国的に拡散 したことを，栽培技術の進歩に起因するとし，それは小農技術の域を出ていないこと， したがって，その技術ならびに技術を基礎にして実現した生産力の水準が急速に平準化 したことを強調した。ビニールハウスやトンネル栽培も，小農にも導入しやすい技術で あり，当然，特定の地域だけでなく，全国的に拡散してしまう可能性をもっている。

先行していた野菜産地も, その有利性がいつまでも続くのではない。長年，果菜類の ハウス栽培で冬のマーケットを支配して来た高知県が，新興の宮崎県におびやかされる に至っているというのも, 技術の平準化現象の一例であろら。それに対応するために, 先行の産地は, 経営の装備内容を高度化する途を選ぶ。八ウスの加温装置とか, 換気 扇，自動灌水などの施設自体の効率を高めるだけでなく，八ウス面積の抎大とか，自動 車の大型化なども推進される。農家は，農業近代化資金などの融資を個別的に受けるほ か，先行産地として得た特別利潤を拡大再生産の方向へ向って投資する。

従来からの産地が, 生産力水準の上昇をめざして, 現状を改善する場合は, 農家個別 の努力で行われてきた傾向が強かった。こういら地域では, 産地の古さと個別性が炎い となって, 発展を妨げることもある。農家間の階層差や経営型が大きく分化してしまっ た後では，とくに問題が滞る。たとえば，ハウス一棟当りの面積を拡大するために必要 な耕地の交換分合が，古い産地では簡単には達成しにくいということも生じやすい。こ れに対して, 新しく産地の形成を目指すところは, 現在, 最も効率のよいと考学られる 生産・流通上の設備投資を計画的・組織的に怙こなう。野菜生産出荷近代化事業や農業 構造改善の資金を受けて，基盤整備事業や近代化施設導入事業を大規模かつ急速に行っ た地域は，時間的な括くれをとり戻して，生産力水準としてはトップクラスの産地とし てスタートすることになる。

野菜の産地は変化しやすいといわれ, 事実, 今日はその変化が全国的に著しい。しか し，落着くべきところに落着く傾向は見せつつあり，それを促進しているのが資本の投 下であり，生産手段の集約化である。随伴的に生ずる技術水準の向上は，それ自体が強 い立地条件となって，産地間競争は果てることがない。

本稿執筆に際して, 農林省農業技術研究所河野敏明氏に貴重な示唆をいただいたこと を感謝したい。

(山形大学教養部助教授)

7）美土路達雄：青果物の市場体系序説，協同組合経営研究月報（1960）86, pp. 2 14. 山田定市：そ菜主産地の展開と農業協同組合, 北海道農林研究（1965）26, pp. 20４3. 